\title{
MICHAŁ STRZELBICKI
}

ORCID: 0000-0002-4422-3076

Uniwersytet im. Adama Mickiewicza w Poznaniu

michal.strzelbicki@amu.edu.pl

\section{Kryptowaluty jako przedmiot działalności gospodarczej - wybrane uwagi}

\begin{abstract}
Abstrakt: Artykuł jest próbą udzielenia odpowiedzi na pytania związane z wykorzystaniem kryptowalut w działalności gospodarczej. Temat główny Zjazdu Katedr i Zakładów Publicznego Prawa Gospodarczego „Państwo a przedsiębiorca — aktualne wyzwania” skłania do poszukiwania nowych zjawisk w obszarze działalności gospodarczej, których pojawienie się może wymagać objęcia ich regulacją prawną. Takim zjawiskiem, które od co najmniej kilku lat stopniowo zyskuje na znaczeniu w obrocie gospodarczym, są kryptowaluty. Pojawieniu się kryptowalut towarzyszy zaistnienie nowych przedmiotów działalności przedsiębiorców związanych zarówno z ich pozyskiwaniem (na przykład tak zwany mining, czyli „kopanie” kryptowalut), jak i następnie z obrotem nimi (na przykład tak zwane giełdy kryptowalut). Z perspektywy ochrony interesu publicznego uważnego namysłu wymaga, czy dotychczasowe przepisy prawne należycie te zjawiska identyfikują i regulują. W szczególności odpowiedzi wymagają pytania, czy czynności związane z pozyskiwaniem i obrotem kryptowalutami stanowią działalność gospodarczą, a dalej - w razie pozytywnej odpowiedzi na to pytanie — czy działalność tego rodzaju jest działalnością wolną czy działalnością reglamentowaną.
\end{abstract}

Słowa kluczowe: kryptowaluty, działalność gospodarcza, giełdy kryptowalut, świadczenie usług płatniczych.

Temat główny Zjazdu Katedr i Zakładów Publicznego Prawa Gospodarczego „Państwo a przedsiębiorca - aktualne wyzwania” skłania do poszukiwania nowych zjawisk w obszarze działalności gospodarczej, których pojawienie się może wymagać objęcia ich regulacją prawną. Takim zjawiskiem, które od co najmniej kilku lat stopniowo zyskuje na znaczeniu w obrocie gospodarczym, są kryptowaluty. Pojawieniu się kryptowalut towarzyszy rozwój nowych przedmiotów działalności przedsiębiorców, związanych zarówno z ich pozyskiwaniem (na przykład tak zwany mining, czyli „kopanie” kryptowalut), jak i następnie z obrotem nimi (na przykład tak zwane giełdy kryptowalut). Z perspektywy ochrony interesu publicznego uważnego namysłu wymaga, czy dotychczasowe przepisy prawne należycie 
te zjawiska identyfikują $\mathrm{i}$ je regulują. W szczególności odpowiedzi wymagają pytania, czy czynności związane z pozyskiwaniem i obrotem kryptowalutami stanowią działalność gospodarczą w rozumieniu art. 3 ustawy Prawo przedsiębiorców ${ }^{1}$, a dalej — w razie pozytywnej odpowiedzi — czy działalność tego rodzaju jest (względnie - powinna być) działalnością wolną czy działalnością reglamentowaną ${ }^{2}$. Niniejszy artykuł stanowi próbę poszukiwania odpowiedzi na tak postawione pytania.

\section{Kryptowaluty — charakterystyka ogólna}

Punktem wyjścia do dalszych rozważań musi być, z konieczności skrótowa, charakterystyka kryptowalut ${ }^{3}$. Kryptowaluty są postacią walut wirtualnych, których definicję legalną zawiera art. 2 ust. 2 pkt 26 ustawy z dnia 1 marca 2018 roku o przeciwdziałaniu praniu pieniędzy i finansowaniu terroryzmu ${ }^{4}$. Zgodnie $\mathrm{z}$ tą regulacją, walutą wirtualną jest cyfrowe odwzorowanie wartości, które nie jest: a) prawnym środkiem płatniczym emitowanym przez NBP, zagraniczne banki centralne lub inne organy administracji publicznej; b) międzynarodową jednostką roz-

1 Ustawa z dnia 6 marca 2018 roku Prawo przedsiębiorców, Dz.U. z 2018 r. poz. 646 ze zm., dalej: upp.

$2 \mathrm{~W}$ niniejszym opracowaniu posługuję się wąskim rozumieniem reglamentacji działalności gospodarczej (tak zwana reglamentacja sensu stricto), które w doktrynie publicznego prawa gospodarczego sprowadzane jest do ograniczania wolności gospodarczej na drodze wprowadzania obowiązku uzyskania przez przedsiębiorcę koncesji, zezwolenia (licencji, zgody) czy wpisu w rejestrze działalności regulowanej; por. przegląd stanowisk znajdujących się w pracy M. Waligórskiego, $A d$ ministracyjnoprawna reglamentacja działalności gospodarczej, Poznań 1994, s. 23-27; zob. także między innymi T. Kocowski, Reglamentacja działalności gospodarczej, [w:] System Prawa Administracyjnego, t. 8a. Publiczne prawo gospodarcze, red. J. Grabowski, L. Kieres, A. Walaszek-Pyzioł, Warszawa 2013, s. 679 n.; M. Szydło, Swoboda działalności gospodarczej, Warszawa 2005, s. 203 n. Istotą wąsko rozumianej reglamentacji działalności gospodarczej, a jednocześnie spoiwem łączącym koncesje, zezwolenia i rejestry działalności regulowanej, nie jest forma prawna, w której organ dopuszcza przedsiębiorcę do podjęcia działalności gospodarczej, ale istnienie szczególnego związku między nabyciem i posiadaniem przez przedsiębiorcę prawa do podjęcia i wykonywania działalności gospodarczej danego rodzaju, a spełnieniem przez niego szczególnych warunków wykonywania tejże działalności; por. M. Strzelbicki, Reglamentacja działalności gospodarczej w świetle ustawy Prawo przedsiębiorców na tle unormowań wcześniejszych, RPEiS 2018, z. 4, s. 73 n.

3 W literaturze toczy się dyskusja w kwestii ustalenia, czy w istocie kryptowaluty są; por. między innymi K. Zacharzewski, Obrót walutami cyfrowymi w reżimie obrotu instrumentami finansowymi, „Przegląd Sądowy” 2017, nr 11-12, s. 140; J. Szewczyk, O cywilnoprawnych aspektach bitcoina, „Monitor Prawniczy” 2018, nr 5, s. 243; J. Szewczyk, O cywilnoprawnych aspektach bitcoina (cz. II), „Monitor Prawniczy” 2018, nr 6, s. 304; J. Dąbrowska, Charakter prawny bitcoin, „Człowiek w Cyberprzestrzeni” 2017, nr 1, s. 57 n.; E. Wanat, Bitcoin i inne kryptowaluty jako przedmiot świadczenia pieniężnego, „Transformacje Prawa Prywatnego” 2019, nr 2, s. 79 n.; W. Srokosz, Publicznoprawne ograniczenia kryptowalut, [w:] Jednostka wobec dziatań administracji publicznej, red. E. Ura, E. Feret, S. Pieprzny, Rzeszów 2016, s. 600 n.

4 Dz.U. z 2018 r. poz. 723 ze zm.; dalej: ufinter. 
rachunkową ustanawianą przez organizację międzynarodową i akceptowaną przez poszczególne kraje należące do tej organizacji lub z nią współpracujące; c) pieniądzem elektronicznym w rozumieniu ustawy z dnia 19 sierpnia 2011 roku o usługach płatniczych; d) instrumentem finansowym w rozumieniu ustawy z dnia 29 lipca 2005 roku o obrocie instrumentami finansowymi; e) wekslem lub czekiem — oraz które jest wymienialne w obrocie gospodarczym na prawne środki płatnicze i akceptowane jako środek wymiany, a także może być elektronicznie przechowywane lub przeniesione albo może być przedmiotem handlu elektronicznego ${ }^{5}$. Kryptowaluty cechują się przy tym tak zwanym dwukierunkowym przepływem, to znaczy umożliwiają ich nabywanie i zbywanie (wymianę) na waluty tradycyjne (prawne środki płatnicze). Nadto są one interoperacyjne ze światem rzeczywistym, to znaczy pozwalają nie tylko na wymianę na walutę tradycyjną, ale także bezpośrednio na nabycie nie tylko wirtualnych, ale także rzeczywiście istniejących dóbr i usług oferowanych przed podmioty akceptujące kryptowaluty jako środek płatniczy ${ }^{6}$.

\section{Giełdy kryptowalut}

Dotychczas obserwowana praktyka rynkowa wskazuje na dwa najczęściej występujące sposoby wykorzystania kryptowalut jako przedmiotu prowadzonej działalności gospodarczej ${ }^{7}$. Pierwszą z nich jest tak zwana giełda kryptowalut,

${ }^{5}$ Do kategorii walut wirtualnych, obok kryptowalut, należą także scentralizowane waluty cyfrowe, które są emitowane przez podmioty prywatne i które mogą być wykorzystywane w pewnym zamkniętym środowisku (na przykład gry komputerowej - w celu nabywania dodatkowych usług wpływających na jakość rozgrywki); kryptowaluty oraz scentralizowane waluty cyfrowe tworzą kategorię prywatnego pieniądza cyfrowego - por. E. Wanat, op. cit., s. 83-84.

${ }^{6}$ Zgodnie z raportem Europejskiego Banku Centralnego z 2012 roku kryptowaluty mogą być zdefiniowane jako rodzaj cyfrowych pieniędzy prywatnych, kreowanych, kontrolowanych, używanych i akceptowanych przez członków danej społeczności wirtualnej; Europejski Bank Centralny, Virtual Currency Schemes, 2012, https://www.ecb.europa.eu/pub/pdf/other/virtualcurrencyschemes201210en.pdf (dostęp: 19.09.2019); natomiast w raporcie EBC z 2015 roku określono je jako wirtualne odzwierciedlenie wartości, które nie jest emitowane przez bank centralny, instytucję kredytową lub emitenta pieniądza elektronicznego i które, w niektórych okolicznościach, może stanowić alternatywę wobec pieniądza; Europejski Bank Centralny, Virtual Currency Schemes - a further analysis, 2015, https://www.ecb.europa.eu/pub/pdf/other/virtualcurrencyschemesen.pdf (dostęp: 19.09.2019). Z kolei Europejski Urząd Nadzoru Bankowego w raporcie z dnia 9 stycznia 2019 roku za kryptoaktywa uznał oparte na kryptografii, technologii rejestrów rozproszonych lub też innej podobnej technologii, niegwarantowane i niewydawane przez banki centralne (a zatem nie-pieniądze), używane na potrzeby wymiany, inwestycji (na przykład ICO) lub dostępu do określonych dóbr lub usług (utility tokens); https://eba.europa.eu/documents/10180/2545547/EBA+Report+on+crypto+assets. pdf (dostęp 18.09.2019); por. też J. Szewczyk, O cywilnoprawnych aspektach bitcoina ..., s. 243 n.

7 Z uwagi na dynamicznie zachodzące zmiany na rynku i rozwój kryptowalut nie są to jedyne rodzaje działalności gospodarczej mogącej mieć za przedmiot wykorzystanie kryptowalut; ograniczone ramy artykułu nie pozwalają jednak na ich omówienie w tym miejscu. 
której istota (analogicznie jak w rozpoznawanej przez TSUE sprawie C-264/14 ${ }^{8}$ ) polega na wymianie walut tradycyjnych na kryptowalutę, przy czym prowadzący giełdę podmiot realizuje swój cel zarobkowy, najczęściej opierając się na różnicy pomiędzy kursem kupna a kursem sprzedaży kryptowaluty. Nie może ulegać (w mojej ocenie) wątpliwości, że działalność tego rodzaju wyczerpuje definicję działalności gospodarczej, zawartą w art. 3 ustawy Prawo przedsiębiorców. Bezspornie giełda kryptowalut jest działalnością zorganizowaną i działalnością ciągłą. Przemawia za tym choćby fakt, że istotą działalności giełdy jest prowadzenie powtarzalnych operacji wymiany walut tradycyjnych na kryptowaluty i odwrotnie, które przeprowadzane są przy użyciu specjalistycznego oprogramowania, przeznaczonego do tego rodzaju działalności. Funkcjonowanie giełdy kryptowalut wymaga nadto wprowadzenia przez podmiot prowadzący giełdę szeregu regulacji, w tym regulaminu określającego prawa i obowiązki uczestników obrotu oraz samego organizatora. Działalność giełdy kryptowalut jest również działalnością zarobkową, ponieważ prowadzący ją przedsiębiorca zmierza do uzyskania zysku będącego nadwyżką między przychodami a kosztami ich osiągnięcia. Przeszkodą w uznaniu tej działalności jako zarobkowej nie jest nawet fakt, że prowadzący ją podmiot nie musi od uczestników transakcji pobierać żadnych opłat czy prowizji - jak trafnie wskazał TSUE, cel zarobkowy nie musi przybierać formy bezpośredniej odpłatności, a może także przejawiać się w marży wynikającej z różnicy między ceną sprzedaży a ceną zakupu ${ }^{9}$. Dokonana przez TSUE wykładnia celu zarobkowego działalności jest — w mojej ocenie — adekwatna także do interpretacji przepisu art. 3 upp w tym zakresie.

Inną kwestią jest odpowiedź na pytanie, czy prowadzenie giełdy kryptowalut jest działalnością wolną czy reglamentowaną oraz jakie akty prawne mogą mieć zastosowanie do regulacji tego rodzaju działalności. Należy zauważyć, że obrót kryptowalutami, z uwagi na jego anonimowość i rozproszenie w sieci, wymyka się regulacji prawnej. Obrót samymi kryptowalutami nie wymaga uzyskania zezwolenia ani nie jest działalnością regulowaną ${ }^{10}$. Momentem, w którym moż-

8 Sprawa C-264/14 Skatteverket v. D. Hedqvist, Zb. Orz. 2015, poz. 718; TSUE orzekł, że transakcje wymiany waluty tradycyjnej na jednostki waluty bitcoin i odwrotnie stanowią odpłatne świadczenie usług w rozumieniu art. 24 ust. 1 w zw. z art. 2 ust. 1 lit. c) dyrektywy Rady 2006/112/ WE z dnia 28 listopada 2006 roku w sprawie wspólnego systemu podatku od wartości dodanej, Dz.U. L 347, s. 1; dalej: dyrektywa VAT), które to transakcje są zwolnione od podatku od towarów i usług VAT na podstawie art. 135 ust. 1 lit. e) dyrektywy VAT.

${ }^{9}$ Również w krajowej doktrynie wskazuje się, że do oceny zarobkowego charakteru działalności gospodarczej nie można utożsamiać go z odpłatnością dotyczącą relacji między przedsiębiorcą a jego klientem; por. E. Komierzyńska-Orlińska, [w:] Konstytucja biznesu. Komentarz, red. M. Wierzbowski, Warszawa 2019, s. 54; S. Koroluk, Cechy działalności gospodarczej w świetle ustawy o swobodzie działalności gospodarczej, [w:] A. Powałowski, S. Koroluk, Podejmowanie działalności gospodarczej w świetle regulacji prawnych, Bydgoszcz-Gdańsk 2005, s. 34.

10 T. Klecor, Licencja dla giełdy kryptowalut, https://legalgeek.pl/licencja-dla-gieldy-kryptowalut/ (dostęp: 19.09.2019); nie stanowi on też usługi płatniczej — tak Minister Finansów w piśmie 
liwe staje się zidentyfikowanie uczestników tego obrotu (a pośrednio — źródeł pochodzenia oraz przeznaczenia kryptowaluty), jest wymiana kryptowaluty na walutę tradycyjną (prawny środek płatniczy). Nie dziwi zatem, że właśnie interoperacyjność kryptowalut jest tą sferą, którą państwa starają się poddać regulacji prawnej. Odnosząc się do obowiązujących w Polsce regulacji, w pierwszej kolejności zauważmy, że wymiana kryptowalut, także na tradycyjne waluty, nie jest działalnością kantorową, o której mowa w przepisach ustawy z dnia 27 lipca 2002 roku Prawo dewizowe ${ }^{11}$. Z omawianej perspektywy kluczowe znaczenie ma natomiast możliwość uznania usług świadczonych przez giełdę kryptowalut jako świadczenia usługi płatniczej w rozumieniu przepisów ustawy z dnia 19 sierpnia 2011 roku o usługach płatniczych ${ }^{12}$. Ustawa definiuje usługi płatnicze w art. 3 ust. 1, posługując się zamkniętym ich katalogiem, od którego przewidziano wyjątki w art. 6 ustawy. Jednocześnie w art. 4 ust. 2 ustawy określono, jakie kategorie podmiotów mogą być dostawcami usług płatniczych, a w dalszych przepisach ustawy — jakie obowiązki natury reglamentacynej winny zostać przez te podmioty spełnione. Różnorodność konstrukcji prawnych przyjmowanych przez twórców giełd kryptowalut utrudnia wyprowadzenie uniwersalnych wniosków co do ich podlegania pod przepisy ustawy o usługach płatniczych — zależy to $\mathrm{w}$ znacznej mierze od tego, czy na jakimkolwiek etapie transakcji giełda kryptowalut faktycznie wchodzi w posiadanie środków pieniężnych (waluty tradycyjnej) należących do jej klienta i w jaki sposób pośredniczy w ich przekazaniu nabywcy ${ }^{13}$. Można jednak postawić tezę, że ustawodawca, w ślad za prawodawcą unijnym, implementując dyrektywę PSD2 ${ }^{14}$, rozszerzył zakres pojęcia

skierowanym do Marszałka Senatu z dnia 28 czerwca 2013 roku, https://www.senat.gov.pl/gfx/senat/ userfiles/_public/k8/dokumenty/stenogram/oswiadczenia/klima/3001oa.pdf (dostęp: 7.10.2019).

11 Dz.U. z 2002 r. Nr 141, poz. 1178 ze zm.; zgodnie z art. 2 ust. 1 pkt 19 ustawy działalnością kantorową jest regulowana działalność gospodarcza polegająca na kupnie i sprzedaży wartości dewizowych oraz pośrednictwie $\mathrm{w}$ ich kupnie i sprzedaży, przy czym wartościami dewizowymi są zagraniczne środki płatnicze oraz złoto dewizowe i platyna dewizowa, a przez zagraniczne środki płatnicze rozumie się waluty obce (zagraniczne prawne środki płatnicze) i dewizy, to jest papiery wartościowe i inne dokumenty pełniące funkcję środka płatniczego, wystawione w walutach obcych — kryptowaluta nie należy do żadnej z tych kategorii.

12 Dz.U. z 2007 r. poz. 2003 ze zm.; kwalifikacja ta ma również istotne implikacje prawnokarne, ponieważ zgodnie z art. 150 przywołanej ustawy: „Kto, nie będąc uprawnionym, prowadzi działalność w zakresie świadczenia usług płatniczych lub w zakresie wydawania pieniądza elektronicznego, podlega grzywnie do 5000000 złotych albo karze pozbawienia wolności do lat 2, albo obu tym karom łącznie".

${ }^{13}$ W najczęściej dotąd spotykanym modelu środki pieniężne od nabywcy trafiają na rachunek bankowy giełdy, która następnie wypłaca je sprzedającemu; T. Klecor, Giełdy kryptowalut pod nadzorem KNF? Czy PSD2 i wpis BitBay na listę ostrzeżeń publicznych zmienia zasady gry?, https:// legalgeek.pl/gieldy-kryptowalut-pod-nadzorem-knf-czy-psd2-i-wpis-bitbay-na-liste-ostrzezen-publicznych-zmienia-zasady-gry/ (dostęp 19.09.2019).

14 Ustawa z dnia 10 maja 2018 roku o zmianie ustawy o usługach płatniczych oraz niektórych innych ustaw, Dz.U. z 2018 r. poz. 1075; ustawa nowelizuje ustawę z dnia 19 sierpnia 2011 roku o usługach płatniczych, Dz.U. z 2011 r. Nr 199, poz. 1175 ze zm., dalej: uup; oraz impementuje 
usługi płatniczej w ten sposób, by objąć nim także te giełdy kryptowalut, które regulacji prawnej wcześniej się wymykały. Jest to widoczne w dwóch płaszczyznach. Pierwszą z nich jest modyfikacja wyłączenia zastosowania przepisów uup zapisana w art. 6 pkt 2 ustawy, to jest transakcji płatniczych między płatnikiem a odbiorcą dokonywanych za pośrednictwem umocowanej osoby wykonującej czynności zmierzające do zawarcia przez płatnika i odbiorcę oznaczonej umowy lub zawierającej taką umowę. Przed nowelizacją wyłączenie to dotyczyło także pośredników reprezentujących obie strony transakcji (co najczęściej miało miejsce $\mathrm{w}$ przypadku giełd kryptowalut). Na skutek nowelizacji ze świadczeniem usług płatniczych w tym zakresie nie mamy do czynienia tylko wówczas, gdy podmiot reprezentuje wyłącznie jedną stronę transakcji ${ }^{15}$. Podmioty prowadzące giełdy kryptowalut, stosujące model reprezentowania obu stron transakcji, przestały być zatem objęte przywołanym wyłączeniem, a tym samym muszą liczyć się z koniecznością zastosowania uup do ich działalności ${ }^{16}$. Po drugie, zgodnie z nowelizacją uup, za usługę płatniczą należy uznać także usługę świadczoną w mechanizmie PIS (payment initiation service; usługa inicjowania transakcji płatniczej, art. 3 ust. 1 pkt $7^{17}$ ). W przypadku tego rodzaju usługi płatniczej podmiot ją świadczący w ogóle nie wchodzi w posiadanie środków pieniężnych należących do klienta, a mimo to podpada pod reżim uup, co, jak się wydaje, dodatkowo utrudni prowadzącym giełdy kryptowalut takie ukształtowanie zasad prowadzonej działalności, które pozwoliłoby na uniknięcie zastosowania przepisów uup ${ }^{18}$. Objęcie giełdy kryptowalut przepisami ustawy o usługach płatniczych ma tę konsekwencję dla podmiotu giełdę prowadzącego, że musi on dokonać wyboru jednej z form wykonywania działalności określonych przepisami ustawy (tak zwanego dostawcę usług płatniczych — zamknięty katalog dostawców zawarto w art. 4 ust. 2 uup), spełnić warunki jej prowadzenia i ostatecznie uzyskać od KNF stosowne zezwolenie, względnie wpis w rejestrze działalności regulowanej ${ }^{19}$. Warto jednak w tym miejscu dodać, że objęcie danej działalności gospodarczej re-

dyrektywę Parlamentu Europejskiego i Rady nr 2015/2366 z dnia 25 listopada 2015 roku w sprawie usług płatniczych w ramach rynku wewnętrznego, zmieniająca dyrektywy 2002/65/WE, 2009/110/ WE, 2013/36/WE i rozporządzenie (UE) nr 1093/2010 oraz uchylająca dyrektywę 2007/64/WE, Dz.Urz. UE L 337 z 23.12.2015 (dalej: PSD2).

15 P. Turski, Gietdy kryptowalut po prawnym liftingu, https://www.filipiakbabicz.com/ przestepstwa-w-biznesie/2018/09/12/kryptogieldy-w-kontekscie-psd2/ (dostęp: 18.09.2019).

16 T. Klecor, Giełdy kryptowalut...

17 Zgodnie z art. 3 ust. 5 uup usługa inicjowania transakcji płatniczej oznacza usługę polegającą na zainicjowaniu zlecenia płatniczego przez dostawcę świadczącego usługę inicjowania transakcji płatniczej na wniosek użytkownika z rachunku płatniczego użytkownika prowadzonego przez innego dostawcę.

18 P. Turski, op. cit.

19 Wskazuje się, że w grę mogą wchodzić następujące formy: biuro usług płatniczych, BIP (art. 118 n. uup), mała instytucja płatnicza, dalej: MIP (art. 117F n. uup) oraz krajowa instytucja płatnicza, dalej: KIP (art. 60 n. uup); na temat wad i zalet każdej z tych form por. T. Klecor, Gietdy krypotwalut...; idem, Licencja dla giełdy... 
glamentacją niekoniecznie musi wiązać się dla przedsiębiorcy z negatywnymi konsekwencjami. Prawdą jest, że konieczność spełnienia ustawowych wymagań podjęcia działalności generuje koszty dla przedsiębiorcy oraz może być dla niego organizacyjnym wyzwaniem. Z tej perspektywy, w doktrynie publicznego prawa gospodarczego, reglamentacja działalności gospodarczej słusznie postrzegana jest jako ograniczenie wolności gospodarczej ${ }^{20}$. Nie można jednak pomijać faktu, że uzyskanie przez przedsiębiorcę zezwolenia stanowi swoiste poświadczenie przez organ reglamentujący, że przedsiębiorca spełnia warunki legalnego wykonywania działalności gospodarczej określonego rodzaju ${ }^{21}$. Tym samym posiadanie przez przedsiębiorcę prowadzącego giełdę kryptowalut zezwolenia (odnośnie do KIP), ewentualnie wpisu w rejestrze działalności regulowanej (dotyczącego MIP), zwiększać będzie zaufanie do jego działalności, co w sektorze finansowym ma niebagatelne znaczenie i może być dla przedsiębiorcy istotną rynkową wartością. Do działalności polegającej na prowadzeniu giełdy kryptowalut zastosowanie znajdzie nadto wiele dalszych aktów prawnych, nakładających na przedsiębiorców obowiązki natury publicznoprawnej, w tym między innymi regulacje ustawy o przeciwdziałaniu praniu pieniędzy i finansowaniu terroryzmu. Wymagają one stosowania tak zwanych środków bezpieczeństwa finansowego, w tym między innymi przeprowadzenia identyfikacji oraz weryfikacji tożsamości klienta giełdy ${ }^{22}$.

\section{Pierwotne pozyskiwanie kryptowaluty}

Innego rodzaju działalność, w której kryptowaluta pełni funkcję przedmiotu podejmowanych działań, jest tak zwany mining (kopanie kryptowalut). Technologia blockchain, na której podstawie kryptowaluty funkcjonują, polega na uwierzytelnianiu transakcji poprzez samych użytkowników systemu oraz zapisywaniu danych o transakcjach w zaszyfrowanych blokach ustawianych w łańcuchy ${ }^{23}$.

20 T. Kocowski, Reglamentacja gospodarcza, [w:] A. Borkowski et al., Administracyjne prawo gospodarcze, Wrocław 2005, s. 508; M. Szydło, op. cit., s. 204.

21 Por. C. Kosikowski, Problemy reglamentacji działalności w Polsce, [w:] Instytucje wspótczesnego prawa administracyjnego, Kraków 2001, s. 363; M. Strzelbicki, Wpis do rejestru działalności regulowanej, RPEiS 2005, z. 4, s. 75; ta sama uwaga dotyczy także koncesji, w mniejszym stopniu natomiast wpisu w rejestrze działalności regulowanej, a to z uwagi na brak kontroli wstępnej poprzedzającej wpis przedsięborcy do rejestru.

22 Art. 33 ust. 1 w zw. z art. 34 ust. 1 i w zw. z art. 2 ust. 1 pkt 3 ufinter.

23 Technologia rozproszonego rejestru, ang. distributed ledger technology, DLT. Istotą blockchain, techonologii wprowadzonej przez osobę lub grupę osób działających pod pseudonimem Satoshi Nakamoto w 2008 roku, jest utrzymanie wspólnej i zbiorowej księgi rachunkowej transakcji w postaci cyfrowej, rozproszonej po całej sieci, w takich samych kopiach. Blockchain jest publicznym rejestrem transakcji zapisywanych w porządku chronologicznym. Technologia ta opiera się na tak zwanej sieci peer-to-peer pozbawionej centralnych komputerów, systemów zarządzających i we- 
Zapisy $\mathrm{w}$ tej bazie danych dokonywane są $\mathrm{z}$ zastosowaną metodą kryptografii (szyfrowania) ${ }^{24}$. Tworzenie bloków, ich szyfrowanie oraz rozsyłanie wymaga znacznych mocy obliczeniowych. W klasycznej bankowości moce obliczeniowe (infrastrukturę) potrzebne do obsługi transakcji zapewnia podmiot prowadzący te rozliczenia, na przykład bank. W przypadku kryptowalut opartych na blockchain tak zwana zaufana osoba trzecia (na przykład bank) zostaje jednak pominięta, a transakcje wykonywane są między samymi użytkownikami. Nie ma zatem scentralizowanego podmiotu, który byłby odpowiedzialny za zapewnienie infrastruktury (mocy obliczeniowej) niezbędnej do funkcjonowania systemu, w tym zabezpieczenie informacji o dokonanych transakcjach. Infrastrukturę blockchain tworzą zatem sami użytkownicy, którzy mogą udostępniać swoje komputery na użytek procesu uwierzytelniania transakcji i tworzenia nowych bloków, nazywanego miningiem (kopaniem kryptowalut) ${ }^{25}$. Kopanie kryptowalut wymaga znacznych mocy obliczeniowych, zapewnianych przez odpowiedni do tego sprzęt komputerowy (nazywany koparkami) i oprogramowanie, a nadto wymaga znacznego poboru energii elektrycznej ${ }^{26}$ - generuje zatem znaczne koszty po stronie tak zwanego górnika. Z tego względu wspierający kopanie kryptowalut algorytm zapewnia „górnikowi” pozyskiwanie określonej ilości kryptowaluty ${ }^{27}$ mającej stanowić dla niego wynagrodzenie za ponoszone koszty. Rentowność miningu zależy zatem przede wszystkim od kosztów energii elektrycznej oraz od kursu

ryfikujących transakcje. Każdy komputer w sieci może brać udział w przesyłaniu i uwierzytelnianiu transakcji. W przypadku blockchain będą to bloki w ramach księgi transakcji. Księga jest otwarta dla wszystkich, ale przed niepowołanym dostępem w pełni zabezpieczona przez skomplikowane narzędzia kryptograficzne. Użytkownik ma wgląd tylko w swoje transakcje. Dzięki temu zapisowi transakcje są publiczne, ale dostępne tylko w ramach praw dostępu dla danego użytkownika i całą ich historię, od samego początku istnienia blockchain aż do dziś można przejrzeć i zweryfikować; por. N. Biedrzycki, Co to jest blockchain - wszystko co trzeba o nim wiedzieć, https://norbertbiedrzycki. pl/blockchain-trzeba-o-nim-wiedziec/ (dostęp: 18.09.2019); idem, Czy blockchain jest godzien naszego zaufania?, https://www.forbes.pl/technologie/czy-blockchain-jest-godzien-naszego-zaufania/ wj0m1kj (dostęp: 18.09.2019); aktualny stan systemu wyznaczany jest zawsze przez najdłuższy łańcuch bloków, por. J. Szewczyk, O cywilnoprawnych aspektach bitcoina ..., s. 244.

24 Posiadaną kryptowalutę przechowuje się w cyberportfelach, które są zabezpieczone kluczami - losowo generowanymi ciągami znaków i cyfr.

25 N. Biedrzycki, Blockchain, czyli ostateczny krach systemu finansowego, https://norbertbiedrzycki.pl/blockchain-czyli-ostateczny-krach-systemu-finansowego-2/ (dostęp: 18.09.2019).

26 Według wyników badań prowadzonych przez Cambridge Centre for Alternative Finance funkcjonującego w strukturze Uniwersytetu w Cambridge, szacowane roczne zużycie energii przez koparki kryptowaluty bitcoin wynosi według stanu na 18 września 2019 roku około 77 Twh, https:/www.cbeci.org/ (dostęp: 18.09.2019); wartość ta stanowi ponad 45\% rocznego zużycia energii w Polsce wynoszącego, według danych udostępnianych przez Polskie Sieci Elektoenergetyczne, w 2018 roku około 170 TWh, https://www.pse.pl/dane-systemowe/funkcjonowanie-rb/raporty-roczne-z-funkcjonowania-kse-za-rok/raporty-za-rok-2018\#r6_5 (dostęp: 18.09.2019).

27 Przy czym wygenerowanie nowego bitcoina następuje na wzór loterii, to jest po spełnieniu statystycznie bardzo mało prawdopodobnego warunku; por. J. Szewczyk, O cywilnoprawnych aspektach bitcoina..., s. 244; J. Dąbrowska, op. cit., s. 55. 
pozyskanej kryptowaluty względem waluty krajowej „górnika”. Jak wynika z powyższej charakterystyki, kopanie kryptowaluty to innego rodzaju działalność niż proste nabycie wtórne jej jednostek z zamiarem ich późniejszej odsprzedaży z zyskiem - wymaga ono zaangażowania kapitałowego oraz ponoszenia kosztów obliczonych na osiągnięcie przychodu ze sprzedaży pozyskanych w ten sposób, w sposób pierwotny, jednostek kryptowaluty.

Ujmowanie kopania kryptowalut jako działalności gospodarczej w rozumieniu art. 3 upp może nastręczać trudności. W istocie chodzi o działalność polegającą na wykorzystywaniu (angażowaniu) przez przedsiębiorcę własnego mająt$\mathrm{ku} \mathrm{w}$ celu zarobkowym. Kopanie kryptowalut jest działalnością zarobkową, bo podmiot go prowadzący dąży do uzyskania nadwyżki przychodów nad kosztami. Nie zmienia tej oceny fakt, że uzyskiwana przez górnika jednostka kryptowaluty nabywana jest na skutek działania częściowo losowego algorytmu, a samo nabycie ma charakter pierwotny (to znaczy nabywana jednostka kryptowaluty wcześniej do nikogo nie należała ${ }^{28}$. Kopanie kryptowalut wymaga również posiadania sprzętu komputerowego oraz specjalistycznego oprogramowania oraz polega na stałym podłączeniu tego sprzętu do internetu, co zdaje się - w mojej ocenie wyczerpywać (szeroko rozumiane) przesłanki ciągłości i zorganizowania. Definicja działalności gospodarczej zawarta w art. 2 ustawy o swobodzie działalności gospodarczej ${ }^{29}$ przewidywała jednak nadto, że działalność gospodarcza to działalność wytwórcza, budowlana, handlowa, usługowa oraz poszukiwanie, rozpoznawanie i wydobywanie kopalin ze złóż, a także działalność zawodowa. Wyliczenie to odnosiło się do przedmiotu działalności oraz — w mojej ocenie — wyrażało kolejną przesłankę działalności gospodarczej, to znaczy że wiąże się ona z zaspokajaniem, poza zarobkowymi potrzebami samego przedsiębiorcy, także potrzeb innych podmiotów - nabywców wytwarzanych dóbr lub usług ${ }^{30}$ (bez względu natomiast na to, czy potrzeby te uznamy za uzasadnione, a ich zaspokajanie za społecznie użyteczne czy szkodliwe ${ }^{31}$ ). W kontekście zawartej w art. 2 usdg regulacji w doktrynie wyrażano słuszny pogląd, że to nie przedmiot decyduje o tym, że dana działalność ma charakter gospodarczy oraz że zawarte w przepisie wyliczenie ma charakter przykładowy ${ }^{32}$ i właściwie każdy rodzaj legalnej (to jest nie-

28 J. Dąbrowska, op. cit., s. 56; na gruncie podatkowym natomiast „wykopanie” kryptowaluty nie tworzy zobowiązania podatkowego w podatku dochodowym, a przychód powstaje dopiero w momencie odpłatnego zbycia pozyskanych jednostek; ibidem, s. 70.

29 Ustawa z dnia 2 lipca 2004 roku o swobodzie działalności gospodarczej, Dz.U. z 2004 r. $\mathrm{Nr}$ 173, poz. 1807 ze zm.; dalej: usdg.

30 Podobnie M. Szydło, op. cit., s. 38-39 oraz wskazana tam literatura i orzecznictwo; również w teorii ekonomii gospodarowanie interpretowane jest jako podporządkowane kryteriom racjonalności dokonywanie wyborów w celu zaspokajania potrzeb, M. Rekowski, Wprowadzenie do mikroekonomii, Poznań 2000, s. 11.

31 Por. M. Szydło, op. cit., s. 61 i wskazana tam literatura.

${ }^{32}$ M. Zdyb, M. Sieradzka, Ustawa o swobodzie działalności gospodarczej. Komentarz, Warszawa 2013, s. 34. 
zakazanej) aktywności człowieka może być działalnością gospodarczą (o ile oczywiście jest to aktywność o charakterze gospodarczym, to znaczy spełnione zostaną pozostałe przesłanki zawarte $w$ definicji ${ }^{33}$. Definicja działalności gospodarczej zapisana $w$ art. 3 upp omawianego fragmentu już nie zawiera. Ustawodawca ograniczył się w niej do wskazania cech działalności gospodarczej (działalność zarobkowa, zorganizowana, wykonywana w sposób ciągły i we własnym imieniu), nie nawiązując w żaden sposób do jej przedmiotu. Wydawać by się mogło, że skoro już wcześniej przedmiot wykonywanej działalności o jej kwalifikacji jako gospodarczej nie decydował, że każda niezakazana aktywność może być działalnością gospodarczą, to usunięcie fragmentu definicji zawartej w art. 2 usdg nie wprowadziło żadnej istotnej zmiany. Dla udzielenia odpowiedzi na pytanie, czy kopanie kryptowalut stanowi działalność gospodarczą, wskazana zmiana brzmienia definicji działalności gospodarczej może mieć jednak znaczenie. Jak się wydaje, mining kryptowalut nie mieści się w żadnym z terminów, jakimi do określenia przedmiotu działalności posługiwała się usdg — nie jest on ani działalnością wytwórczą ${ }^{34}$, ani handlową, ani tym bardziej budowlaną czy związaną z górnictwem kopalin. Nie jest również — w mojej ocenie — mining kryptowalut typową działalnością usługową, bo jakkolwiek polega on na udostępnieniu sprzętu komputerowego do wykonywania obliczeń niezbędnych do funkcjonowania technologii blockchain (systemu danej kryptowaluty), to trudno wskazać usługobiorcę, na którego rzecz usługa ta jest świadczona (odbiorcą usługi jest ogół użytkowników kryptowaluty). W świetle definicji działalności gospodarczej zawartej w usdg kwalifikacja kopania kryptowalut byłaby zatem problematyczna ${ }^{35}$. Wątpliwości te zdają się znikać, jeśli odniesiemy się do aktualnie obowiązującej definicji zwartej w art. 3 upp. Jak już wskazano, ustawodawca w żaden sposób nie nawiązuje do przedmiotu działalności, co czyni mining kryptowalut, spełniający kryteria zarobkowości, zorganizowania i ciągłości, działalnością gospodarczą w rozumieniu art. 3 upp. Znaczenia dla kwalifikowania miningu kryptowalut jako działalności gospodarczej nie będzie także miała, budząca wcześniej kontrowersje w doktrynie i orzecznictwie odnośnie do uznawania danej działalności za gospodarczą, ewentualnie niewielka ekonomiczna skala tej działalności ${ }^{36}$. Wprowadzenie przez ustawodawcę przepisu art. 5 upp (tak zwana działalność nieewidencjonowana) ma — w mojej ocenie

33 M. Szydło, op. cit., s. 26.

34 Ponieważ taka powinna prowadzić do wykreowania produktu materialnego, względnie nadania mu określonych cech użytkowych; C. Kosikowski, Komentarz do prawa działalności gospodarczej, [w:] Prawo handlowe, red. C. Kosikowski, t. 1, Warszawa 2001, s. 8-9; podobnie M. Zdyb, M. Sieradzka, op. cit., s. 34; za szerokim rozumieniem działalności wytwórczej, obejmującej także wytwarzanie produktu niematerialnego, opowiada się natomiast T. Kocowski, op. cit., s. 141.

35 Por. M. Szydło, op. cit., s. 37-38, 62 n.; por. T. Kocowski, op. cit., s. 149; zob. też wyrok NSA z dnia 2 marca 1994 roku, sygn. III SA 1433/93, http://www.orzeczenia-nsa.pl/iii-sa-1433-93. html (dostęp: 18.09.2019).

36 Por. wyrok SN z dnia 11 października 1996 roku, III RN 4/96, OSNP 1997, nr 10, poz. 160 , zob. też M. Szydło, op. cit., s. 64. 
— takie znaczenie, że zdaniem ustawodawcy rozmiar danej działalności, mierzony wysokością uzyskiwanych z niej przychodów albo dochodów, nie powinien mieć znaczenia dla kwalifikacji tej działalności jako działalności gospodarczej, chyba że osoba ją prowadząca spełni kryteria wynikające z art. 5 ust. 1 ustawy ${ }^{37}$. Mining kryptowalut jest zatem działalnością gospodarczą bez względu na wysokość osiąganych przez przedsiębiorcę przychodów, chyba że są to przychody mieszczące się $\mathrm{w}$ granicach wynikających $\mathrm{z}$ art. 5 ust. 1 upp. W obowiązującym obecnie ustawodawstwie brakuje natomiast — w mojej ocenie — jakichkolwiek regulacji czyniących z miningu kryptowalut działalność gospodarczą reglamentowaną. Jak się wydaje, brakuje również takiego ważnego interesu publicznego (w rozumieniu art. 22 Konstytucji RP), który uzasadniałby objęcie przez ustawodawcę kopania kryptowalut reglamentacją działalności gospodarczej w przyszłości.

\section{Podsumowanie}

Zjawiska gospodarcze niejednokrotnie wyprzedzają rzeczywistość prawną, czemu szczególnie sprzyja rewolucja cyfrowa, której jesteśmy obecnie świadkami i uczestnikami. Owocem dynamicznego postępu w sferze technologii cyfrowych są między innymi kryptowaluty. Tempo rozwoju rynku kryptowalut oraz stopień ich technicznej złożoności stawiają przed ustawodawcą istotne wyzwanie. Wymaga ono zidentyfikowania aspektów funkcjonowania kryptowalut wymagających regulacji prawnej, następnie ustalenia jej celów i metod, a wreszcie zaprojektowania i wdrożenia konkretnych przepisów podyktowanych ochroną ważnego interesu publicznego. Ustawodawca działa przy tym pod presją czasu, bo brak właściwej regulacji prawnej zagraża interesom uczestników obrotu. Prowadzona w niniejszym opracowaniu analiza dotyczyła regulacji prawnej dwóch sposobów wykorzystywania kryptowalut w działalności gospodarczej, to jest podejmowania i wykonywania działalności gospodarczej polegającej na prowadzeniu giełdy kryptowalut oraz na tak zwanym kopaniu kryptowalut. Jak ustalono, o ile mining kryptowalut mieści się w ogólnych regulacjach dotyczących wykonywania działalności gospodarczej, o tyle prowadzenie giełdy kryptowalut stało się przedmiotem szczegółowych unormowań prawnych. Nie sposób przy tym przecenić znaczenia dorobku prawa unijnego (zarówno w zakresie prawodawstwa, jak i orzecznictwa TSUE), będącego dla polskiego ustawodawcy źródłem istotnych wytycznych przy kształtowaniu treści regulacji krajowych. Czas pokaże nie tylko, czy aktualna regulacja prawna jest wystarczająca do ochrony interesów uczestników obrotu kryptowalutami, ale również czy kryptowaluty znajdą trwałe

37 Oraz że zastosowania nie znajdą wyłączenia spod tej regulacji przewidziane w art. 5 ust. 5 i w art. 44 ust. 3 upp. 
zastosowanie w obrocie gospodarczym, przyczyniając się do rozwoju kolejnych obszarów działalności gospodarczej.

\section{Bibliografia}

Biedrzycki N., Blockchain, czyli ostateczny krach systemu finansowego, https://norbertbiedrzycki. $\mathrm{pl} /$ blockchain-czyli-ostateczny-krach-systemu-finansowego-2/.

Biedrzycki N., Co to jest blockchain - wszystko co trzeba o nim wiedzieć, https://norbertbiedrzycki. pl/blockchain-trzeba-o-nim-wiedziec/.

Biedrzycki N., Czy blockchain jest godzien naszego zaufania?, https://www.forbes.pl/technologie/. czy-blockchain-jest-godzien-naszego-zaufania/wj0m1kj.

Dąbrowska J., Charakter prawny bitcoin, „Człowiek w Cyberprzestrzeni” 2017, nr 1.

Europejski Bank Centralny, Virtual Currency Schemes, 2012, https://www.ecb.europa.eu/pub/pdf/ other/virtualcurrencyschemes201210en.pdf.

Europejski Bank Centralny, Virtual Currency Schemes - a further analysis, 2015, https://www.ecb. europa.eu/pub/pdf/other/virtualcurrencyschemesen.pdf.

Europejski Urząd Nadzoru Bankowego, Report with advice for the European Commission, 2019, https://eba.europa.eu/documents/10180/2545547/EBA+Report+on+crypto+assets.pdf.

Klecor T., Giełdy kryptowalut pod nadzorem KNF? Czy PSD2 $i$ wpis BitBay na listę ostrzeżé publicznych zmienia zasady gry?, https://legalgeek.pl/gieldy-kryptowalut-pod-nadzorem-knfczy-psd2-i-wpis-bitbay-na-liste-ostrzezen-publicznych-zmienia-zasady-gry/.

Klecor T., Licencja dla giełdy kryptowalut, https://legalgeek.pl/licencja-dla-gieldy-kryptowalut/.

Kocowski T., Reglamentacja działalności gospodarczej, [w:] System Prawa Administracyjnego, t. 8a. Publiczne prawo gospodarcze, red. J. Grabowski, L. Kieres, A. Walaszek-Pyzioł, Warszawa 2013.

Kocowski T., Reglamentacja gospodarcza, [w:] A. Borkowski, A. Chełmoński, M. Guziński, K. Kiczka, L. Kieres, T. Kocowski, Administracyjne prawo gospodarcze, Wrocław 2005.

Konstytucja biznesu. Komentarz, M. Wierzbowski, Warszawa 2019.

Koroluk S., Cechy działalności gospodarczej w świetle ustawy o swobodzie działalności gospodarczej, [w:] A. Powałowski, S. Koroluk, Podejmowanie działalności gospodarczej w świetle regulacji prawnych, Bydgoszcz-Gdańsk 2005.

Kosikowski C., Komentarz do prawa działalności gospodarczej, [w:] Prawo handlowe, red. C. Kosikowski, t. 1, Warszawa 2001.

Kosikowski C., Problemy reglamentacji działalności w Polsce, [w:] Instytucje współczesnego prawa administracyjnego, red. I. Skrzydło-Niżnik et al., Kraków 2001.

Rekowski M., Wprowadzenie do mikroekonomii, Poznań 2000.

Srokosz W., Publicznoprawne ograniczenia kryptowalut, [w:] Jednostka wobec działań administracji publicznej, red. E. Ura, E. Feret, S. Pieprzny, Rzeszów 2016.

Strzelbicki M., Reglamentacja działalności gospodarczej w świetle ustawy Prawo przedsiębiorców na tle unormowań wcześniejszych, RPEiS 2018, z. 4.

Strzelbicki M., Wpis do rejestru działalności regulowanej, RPEiS 2005, z. 4.

Szewczyk J., O cywilnoprawnych aspektach bitcoina, „Monitor Prawniczy” 2018, nr 5.

Szewczyk J., O cywilnoprawnych aspektach bitcoina (cz. II), „Monitor Prawniczy” 2018, nr 6.

Szydło M., Swoboda działalności gospodarczej, Warszawa 2005.

Turski P., Giełdy kryptowalut po prawnym liftingu, https://www.filipiakbabicz.com/przestepstwa-w-biznesie/2018/09/12/kryptogieldy-w-kontekscie-psd2.

Waligórski M., Administracyjnoprawna reglamentacja działalności gospodarczej, Poznań 1994. 
Wanat E., Bitcoin i inne kryptowaluty jako przedmiot świadczenia pieniężnego, „Transformacje Prawa Prywatnego" 2019, nr 2.

Zacharzewski K., Obrót walutami cyfrowymi w reżimie obrotu instrumentami finansowymi, „Przegląd Sądowy" 2017, nr 11-12.

Zdyb M., Sieradzka M., Ustawa o swobodzie działalności gospodarczej. Komentarz, Warszawa 2013.

\title{
Cryptocurrencies in economic activity - selected remarks
}

\begin{abstract}
Summary
The article is an attempt to answer the questions related to the use of cryptocurrencies in economic activity. The main theme of the Convention of the Departments of Public Economic Law "The State and the Entrepreneur - Present Challenges" encourages us to seek new phenomena in the business area which, if they occur, may require legal regulation. Such phenomena include cryptocurrencies, which have become increasingly important in recent years. The occurrence of cryptocurrencies has been accompanied with new business areas related to their acquisition (e.g., "mining"), as well as trading (e.g., cryptocurrency exchange). From the perspective of the public interest, it must be carefully analyzed whether the existing legal regulations appropriately identify and regulate such phenomena. In particular, one must answer the questions whether the activities related to acquisition and trading with cryptocurrencies constitutes economic activity in the meaning of the law, and - if they do - whether such business is to be free or regulated.
\end{abstract}

Keywords: cryptocurrencies, economic activity, cryptocurrency exchange, provision of payment services. 